\title{
A Intencionalidade Marcada nos Textos Instrucionais: o que há de novo nisso?
}

The InTENTIONALity MARKED IN InStRUCTIONAL TEXTS: WHAT'S NEW IN IT?

Hilma Ribeiro de Mendonça Ferreira*

Silvia Adélia Henrique Guimarães**

Resumo: Os textos instrucionais têm por finalidade designar procedimentos para os leitores que precisam desempenhar tarefas de diferentes naturezas. Entretanto, apesar de uma similaridade enunciativa pressuposta, encontramos formas de enunciação discursiva discrepantes, dependendo do gênero textual. A partir desse achado, e com base no paradigma interpretativista, a presente pesquisa analisou textos instrucionais de três diferentes gêneros com vistas a observar as intenções que permeiam o tipo textual injuntivo. Mas, também, refletiu sobre como a escola pode se valer desses mecanismos linguísticos para potencializar a leitura dos alunos. Baseados nos Atos de Fala (AUSTIN, 1962; SEARLE, 1969, 1981, 2002), que possibilitaram observar os comandos expostos nos textos, os resultados das análises sugerem que as estruturas frasais usadas para instruir pressupõem níveis impositivos diferentes com que os locutores enunciam os procedimentos. Mostram, também, que o componente ilocucionário e a natureza do gênero em que as frases são usadas constituem os balizadores dessas instruções. Apesar de algumas limitações, como a comparação entre apenas quatro gêneros, quando há vários outros gêneros pertencentes ao tipo injuntivo, os resultados possibilitam uma reflexão crítica sobre a reprodução do pressuposto, principalmente nas escolas básicas, de que a injunção oferece apenas ordens ou comandos.

\footnotetext{
* Doutora em Língua Portuguesa pela Universidade do Estado do Rio de Janeiro (2013). Professora Doutora Adjunto IV - UERJ. Contato: hilmaribeiro1976@gmail.com.

** Mestre em Linguística pela Universidade do Estado do Rio de Janeiro (2011). Professora da Rede Municipal do Rio de Janeiro. Contato: sguimaraes05@hotmail.com.
} 
Palavras-chave: Atos de Fala. Textos instrucionais. Leitura na escola.

Abstract: Instructional texts are intended to designate procedures for readers who need to perform tasks of different nature. However, despite of an assumed expository similarity, we find forms of disparate discursive enunciation, depending on the textual genre. Based on this finding and based on the interpretive paradigm, this research analyses instructional texts from three different genres in order to observe the intentions that underlie the injunctive textual type. This study also reflects on how school can draw on these linguistic mechanisms to enhance students' reading. Based on Speech Acts (AUSTIN 1962; SEARLE, 1969; 1981; 2002), which made it possible to observe the commands exposed in the texts, the analyses results suggest that the phrasal structures used to instruct, assume different imposition levels with which the speakers set out the procedures. The analyses also show that the illocutionary component and the nature of the genre in which phrases are used are the benchmarks of these instructions. Despite some limitations, such as the comparison of only four genres, when there are several other genres of the injunctive type, the results allow a critical reflection on the reproduction of the assumption that the injunction only offers orders or commands particularly in primary schools.

Keywords: Speech Acts. Instructional texts. Reading at school.

\section{Introdução}

... os tolos rejeitam a sabedoria e a instrução (Provérbio de Salomão, Bíblia Sagrada)

O presente estudo partiu de dois objetivos centrais: estudar quatro gêneros instrucionais, considerando os aspectos linguísticos mobilizadores da leitura de textos injuntivos; e refletir sobre como a escola pode trabalhar a leitura de textos injuntivos, mobilizando nos alunos para a conscientização dos procedimentos linguísticos adequados para a compreensão do texto injuntivo. 
Se entendemos a escola como um lugar facilitador para o ensino da leitura eficiente e eficaz, se a vemos como um espaço formal para a construção de um cidadão no mundo - o mundo contemporâneo dialógico -, questionamos: quais oportunidades reais de contato com a leitura os professores têm dado aos alunos? Essas práticas têm de fato propiciado a esses sujeitos os sentidos possíveis do texto, com interação, discussão e apresentação dos elementos linguísticos como pistas concretas para a compreensão textual; ou têm apenas reproduzido a metodologia limitadora e memorizadora da Idade Média?

Com vistas a refletir sobre as perguntas elencadas, concentramo-nos na percepção de que os textos instrucionais, embora apresentem finalidade de uso correspondente - a instrução por meio de frases indicativas de procedimentos -, pressupõem uma predisposição das instruções de formas diferenciadas. A partir dessa primeira noção, constatamos que essas formas de instruir estarão sempre de acordo com as forças ilocutórias relacionadas ao ato diretivo, como preconizado por Searle (2002). Entretanto as frases indicativas de procedimentos também podem mostrar outros atos de fala, se analisadas à luz dos atos locucionário e perlocucionário, para além do nível intencional, intrínseco ao ilocucionário.

Para atingirmos nosso objetivo, analisamos as instruções partindo da materialidade linguística desses textos. A partir dessa análise linguística, consideramos as marcas que pudessem sinalizar os atos de fala comuns às frases de natureza instrucional. Para isso, concentramo-nos nos enunciados instrucionais que se predispõem a mostrar as intenções do locutor ao estipular procedimentos, visto que essas instruções podem demonstrar como ocorrem as configurações comuns ao texto classificado como do tipo injuntivo.

Nos resultados desta análise linguística, percebemos que ocorre uma sobreposição de fatores textuais: 1) o nível das frases, usadas para instruir na leitura; e 2) o nível as ações, unidades subjacentes com valores discursivos que indicam as intenções a serem assumidas a partir das estruturas frasais. Postulamos, portanto, que o tipo textual injuntivo, elucidado por meio das frases indicativas de instruções, pode ser analisado em decorrência dos atos de fala, não ficando restrito apenas às frases tradicionalmente classificadas como "imperativas". 
Nessa perspectiva analítica, as relações entre a intencionalidade e os procedimentos denotam perspectivas acionistas importantes, se o processamento dos sentidos for pensado dessa forma durante a leitura. Com base nesses achados linguísticos, julgamos producente imbricar os resultados das análises e as estratégias de leitura adotadas na escola, pois entendemos que o professor precisa dispor de ferramentas teórico-analíticas para poder provocar a leitura ativa desse aluno.

Para compor o corpus, selecionamos quatro textos instrucionais, sendo um exemplar do gênero textual receita, um do manual, um da bula e um do contrato. Os dados, analisados pela teoria dos atos de fala (AUSTIN, 1962, 1990; SEARLE, 1969, 1981, 2002) possibilitaram uma discussão sobre sua aplicabilidade nos estudos voltados para a leitura na escola.

Para promover a organização textual do trabalho, este artigo está dividido em seções. No primeiro momento, traremos um embasamento teórico que: a) abrange os principais conceitos dos Atos de Fala; b) retoma e distingue os conceitos de tipo e gênero textual; e c) resume os conceitos básicos de leitura aplicada ao ensino. No segundo momento, contextualizamos o trabalho metodologicamente para, finalmente, apresentarmos e discutirmos os dados. Para encerrar, traremos algumas considerações, optando por não denominá-las como "conclusões", principalmente pelo caráter promissor de continuidade deste estudo.

\section{Fundamentação Teórica}

Por ser a natureza acionista da linguagem o eixo central para o entendimento dos usos linguísticos, Austin (1962) e Searle (1969) debruçam-se sobre a questão da performatividade a partir da produção verbal dos indivíduos. Dessa forma, ressaltam-se aspectos importantes nas contribuições dos dois autores, nas subseções a seguir.

\section{Austin e os Ilocucionários e a Natureza Performativa da Linguagem}

John Austin (1962), o principal idealizador do que constitui atualmente a vertente pragmática intitulada "teoria dos atos de fala", concentra seus esforços na caracterização da ação, evidenciando alguns componentes 
importantes da produção verbal dos indivíduos. Desse modo, para além da dicotomia filosófica entre sentido e realidade, Austin postula a evidenciação de três componentes comunicativos que se tornam fundamentais para a exposição aqui proposta. Para o autor, o ato de fala é composto de três partes, três atos simultâneos, “os 'locutórios' (atos de 'dizer qualquer coisa'), os 'ilocutórios' (atos efetuados 'ao dizer qualquer coisa') e os 'perlocutórios' (atos efetuados 'pelo fato de dizer qualquer coisa')" (CHARAUDEAU; MAINGUENAU, 2006, p. 73).

Esses três níveis de atos de fala são desdobrados em suas atribuições das possíveis diferenciações de ações e tipos de atos de fala, inerentes às três “esferas ilocutórias". Também é mérito de seus estudos uma primeira diferenciação dos tipos de atos de fala, pois o autor gerou uma categorização dos subtipos de atos, classificados como "vereditivos", "exercitivos", "compromissivos", "expositivos" e "comportativos".

Contudo, neste artigo, salientamos a dificuldade de caracterização do que constitui o ilocucionário, com respeito à taxonomia, fator já abordado por Rajagopalan (2010). Esse autor destaca que a vinculação do ilocucionário ao verbo performativo, crítica de Searle (2002), é, porém, uma atribuição da qual o próprio Searle não conseguiu se desvencilhar, como mostrado por Rajagopalan (2010).

Por isso, coadunamos nossa visão à de Rajagopalan (1989), que salienta a vinculação da performatividade à natureza do ato ilocucionário, mencionando o fato de que Austin $(1962,1990)$ não abandona a designação "performativo" na caracterização dos enunciados, mesmo depois de desfazer a dicotomia constativo/performativo. Com isso, pode-se acolher a visão defendida por Rajagopalan (1989), na caracterização do ato ilocucionário, como sendo, incontornavelmente "performativos".

Para além dessas discussões teóricas, reconhecemos, entretanto, que, para realizar um ato ilocucionário, é necessário realizar um ato locucionário - para agradecer, por exemplo, é necessariamente dizer certas palavras. E dizer determinadas palavras é, necessariamente, pelo menos em parte, fazer certos movimentos difíceis de descrever com os órgãos vocais. Portanto, o divórcio entre ações físicas e atos de dizer algo não é de todo completo - há uma vinculação (AUSTIN, 1990, p. 98). 
Assim, a teoria dos atos de fala preconiza o fato de que, por meio da palavra, "declaramos", "solicitamos", "saudamos', "coagimos", "prometemos", entre outras ações; e essas falas-ações terão efeitos diferenciados por parte dos interlocutores aos quais essas palavras se direcionam. Existe, portanto, uma relação entre o que é dito e o que é assumido. Por um lado, evidenciam-se níveis de desenvolvimento das ações linguísticas, tal qual estipulado por Austin (1962), ao destacar o "locucionário", o "ilocucionário" e o "perlocucionário". Por outro lado, existem níveis dessas ações, visto que delas emanam “forças ilocutórias", sendo possível categorizálas de acordo com sua natureza discursiva de um modo mais eficiente, como visto com Searle (2002), na proposta categorial, supramencionada.

\section{As Categorias de Atos de Fala Determinadas por Searle (2002)}

Os diferentes modos de instruir, afeitos aos textos instrucionais, levamnos a utilizar a terminologia proposta por Searle (2002) ao equiparar os diferentes atos de fala por suas naturezas e semelhanças. Sobre o agrupamento dessas formas de ação, o autor diferenciou cinco grandes tipos de atos de fala que podem ser enquadrados de acordo com suas características discursivas.

Nesse caso, os atos de fala, de acordo com as características de uso, dividem-se nas classes, designadas pelo autor, como atos/ações "assertivas", “diretivas", "compromissivas”, “expressivas” e “declarações”. São asserções quanto às sentenças que têm por finalidade predispor um conteúdo proposicional que tenha como característica a afirmação de algo como sendo verdadeiro ou não; os diretivos são todos os atos de fala que têm como função promover a tomada de atitudes dos interlocutores a respeito do que é dito, caso dos textos instrucionais; são compromissivos os conteúdos indicadores da postura do falante, quando ele se compromete com algo, futuramente; expressivos são aqueles atos de fala denotadores da emotividade do falante; e, por fim, as declarações constituem enunciados que promovem uma modificação externa como o ato de "declarar guerra" ao inimigo, no sentido bélico.

No Quadro 1, a seguir, elencamos essas categorias a partir das atitudes do falante e dos possíveis posicionamentos dos interlocutores. 
Quadro 1 - As categorias de atos de fala propostas por Searle (1969)

\begin{tabular}{|c|l|l|}
\hline Categorias & \multicolumn{1}{|c|}{$\begin{array}{c}\text { Posicionamento do } \\
\text { falante }\end{array}$} & \multicolumn{1}{|c|}{$\begin{array}{c}\text { Posicionamento do } \\
\text { interlocutor }\end{array}$} \\
\hline Assertivos & $\begin{array}{l}\text { Compromete-se em } \\
\text { afirmar que algo seja falso } \\
\text { ou verdadeiro. }\end{array}$ & $\begin{array}{l}\text { Assume ou não } \\
\text { determinado conteúdo } \\
\text { como sendo falso ou } \\
\text { verdadeiro. }\end{array}$ \\
\hline Diretivos & $\begin{array}{l}\text { Procura fazer com que o } \\
\text { ouvinte realize determinada } \\
\text { tarefa. }\end{array}$ & $\begin{array}{l}\text { Realiza ou não o que o } \\
\text { falante propõe. }\end{array}$ \\
\hline Compromissivos & Propõe-se a realizar algo. & $\begin{array}{l}\text { Acreditar ou não que o } \\
\text { falante realizará algo. }\end{array}$ \\
\hline Expressivos & $\begin{array}{l}\text { Demonstra a emotividade } \\
\text { derivada de algum fator } \\
\text { externo ou interno. } \\
\text { Produz um enunciado que } \\
\text { modifica uma situação } \\
\text { externa. }\end{array}$ & $\begin{array}{l}\text { Compartilha ou não dessa } \\
\text { emotividade. }\end{array}$ \\
\hline
\end{tabular}

No Quadro 1, procuramos resumir o esquema categórico de Searle (2002), que é um importante componente para a análise dos dados a serem apresentados neste artigo. Sobre o esquema de caracterização dos atos de fala, o autor identifica suas características semelhantes a partir de diversos critérios comunicativos, que acolhem também aspectos de ordem psíquica, discursiva, textual e enunciativa.

A fim de evidenciar o entendimento da natureza das instruções feitas nos gêneros escolhidos, inferimos que os "diretivos" se tornam muito importantes na constituição dos textos injuntivos por refletirem as formas de solicitar, o acatamento e as atitudes responsivas dos interlocutores na elaboração das instruções.

Com respeito à força ilocutória dos atos diretivos, para o autor, existem intenções dos falantes, ao utilizar a linguagem, para fazerem suas "performances" enunciativas. Então, podem-se dimensionar diferentes traços discursivos de acordo com os seus posicionamentos, durante a instrução por meio de um diretivo. 
O "contexto de uso" de determinado enunciado é o que promove, portanto, a percepção da sua força ilocutória, bem como dos sentidos possíveis, aferidos a partir do componente proposicional superficial. Nesse caso, a teoria dos atos de fala se revela de grande importância, pois suas perspectivas diferenciam os tipos de esferas das quais emanam as ações enunciativas; e, igualmente, das categorias em que essas ações se inserem.

\section{Tipologia e Gênero: principais conceitos assumidos}

Como nossa pesquisa se debruça sobre textos instrucionais, que são estruturados majoritariamente pelo tipo injuntivo, é válido ressaltar a diferença entre as terminologias "instrucional" e "injuntivo". Ao mencionarmos o primeiro nome, ressaltamos o caráter dos enunciados pesquisados, que têm por finalidade "instruir" e, ao denominarmos o segundo, procuramos evidenciar sua caracterização tipológica dentro do quadro dos tipos textuais.

Em se tratando dos conceitos de "tipo" e "gênero", ambos são indispensáveis, pois permeiam a produção linguística dos indivíduos em qualquer troca interlocutiva. De acordo com a natureza do gênero, a linguagem pode ser contextualizada a partir das formas de manifestação comunicativa, usadas para dar conta das diferentes necessidades de interação discursivas e interpessoais.

Apesar de autores diferentes assumirem nomenclaturas distintas para as diferentes formas textuais, de acordo com quadros teóricos e correntes linguísticas distintas (MARCUSCHI, 2005; CHARAUDEAU, 2008), optamos por acolher a designação de "tipos textuais", sendo essa nomenclatura mais afeita à linguística textual, corrente da linguagem que salienta a esfera de análise da composição material dos textos. A relação entre a linguística textual e essa nomenclatura é salientada por Silva (1999, p. 100), ao afirmar que "alguns estudos desenvolvidos no âmbito da lingüística textual, 'tipo textual' é uma noção que remete ao funcionamento da constituição estrutural do texto[...]".

Assim, nas palavras de Marcuschi (2005, p. 22):

Usamos a expressão tipo textual para designar uma espécie de seqüência teoricamente definida pela natureza lingüística de sua composição 
(aspectos lexicais, sintáticos, tempos verbais, relações lógicas). Em geral, os tipos textuais abrangem cerca de meia dúzia de categorias conhecidas como: narração, argumentação, exposição, descrição, injunção.

Sobre a abordagem do conceito de gênero, ressaltando os diferentes usos da linguagem, é fundamental a observação de Bakhtin (1997) quando cita as atividades de interação humana. O autor faz uma abordagem importante sobre o tema, ao especificar que

Todas as esferas da atividade humana, por mais variadas que sejam, estão relacionadas com a utilização da língua. Não é de surpreender que o caráter e os modos dessa utilização sejam tão variados como as próprias esferas da atividade humana [...]. O enunciado reflete as condições específicas e as finalidades de cada uma dessas esferas, não só por seu conteúdo temático e por seu estilo verbal, ou seja, pela seleção operada nos recursos da língua - recursos lexicais, fraseológicos e gramaticais - mas também, e, sobretudo, por sua construção composicional. (BAKHTIN, 1997, p. 280).

O estudo dos gêneros irá inserir, portanto, um escopo analítico mais abrangente, importante para dimensionar os fatos enunciativos sobre os quais nos referimos no presente trabalho. Apesar dos variados gêneros predominantemente instrucionais - edital, provas, receitas médicas, normas de conduta, regras de jogos, orientações acadêmicas -, neste trabalho, debruçamo-nos sobre quatro deles, todos instrucionais: as receitas, os manuais, as bulas e os contratos, que, embora possuam a mesma função enunciativa, diferem-se quanto às suas aplicações e funções comunicativas.

As receitas, por suas peculiaridades de uso, possuem um arquétipo estrutural mais simplificado: ocorre apenas uma exposição inicial dos ingredientes que serão usados na preparação dos pratos.

Já em se tratando das bulas, pelo fato de instruírem sobre o uso de um medicamento, geralmente, apropriado para a resolução de um problema físico, atribui ao texto elementos compositivos de ordem mais complexa. Fator importante para a configuração textual de maior complexidade das bulas decorre do fato de esse gênero ser direcionado a pelo menos três 
interlocutores distintos, a saber: o paciente, o médico e o farmacêutico. As partes textuais são divididas de acordo com esses interlocutores, informando procedimentos específicos a cada um deles. Dados relativos à composição química são mais apropriados ao farmacêutico; já quando são explicadas as doses necessárias às doenças, ocorrem instruções ao médico; por fim, procedimentos sobre o armazenamento e o aspecto físico do medicamento são mais afeitos aos pacientes.

Os manuais, por sua vez, apresentam como fator diferencial a utilização de algumas remissões a saberes técnicos, pois fazem alusão a especificidades que podem promover dificuldades para o entendimento das instruções. A leitura do manual pode acarretar, por exemplo, o acionamento de conhecimentos de diferentes áreas, necessitando do conhecimento dessas informações a fim de dar conta dos usos requeridos pelos seus interlocutores. A instalação de um aparelho eletrodoméstico, por exemplo, estabelece procedimentos que, muitas vezes, requerem conhecimentos sobre a eletricidade ou sobre a parte mecânica de equipamentos afins, fator que exigirá dos interlocutores atenção na elaboração dos procedimentos.

O último gênero contemplado, o contrato jurídico, possui a mesma finalidade de uso dos demais enunciados, qual seja, a estipulação de procedimentos, mas existem diferenças entre esse gênero e os demais. A maior diferença decorre do fato de que o estabelecimento das diretrizes para o atendimento da contratação de ambas as partes de uma negociação implica na configuração de um texto extenso. Nele, as tarefas precisarão ser expostas de modo a indicar os direitos e os deveres dos dois tipos de alocutários que estarão envolvidos na negociação jurídica/ financeira.

Assim, ressalta-se que o aspecto interlocutivo desses quatro gêneros configurará comandos possuidores de níveis impositivos distintos, de modo a aferir, nas instruções, esses posicionamentos dos locutores. Por consequência do posicionamento quanto à apresentação das instruções, a maior ou a menor precisão quanto ao atendimento dos comandos, pelos interlocutores, é um indicativo importante que pode ser elucidado pelo enquadramento teórico escolhido.

Essas diferenças de valores interlocutivos indicam, todavia, uma equalização, pois, como temos enfatizado, os textos selecionados instruem e são amplamente usados pelos indivíduos, em seu cotidiano. Dadas sua 
relevância e disponibilidade, a escolha dos corpora deu-se de modo a privilegiar textos cuja veiculação é comum para pessoas de diferentes grupos sociais ou etários.

A apropriação das peculiaridades interlocutivas desses quatro gêneros está coadunada, também, com o que fora estipulado por Bakhtin (1997), ao verificar que as situações discursivas corroboram enunciados, de modo a atender a essas demandas, evidenciando, assim, a "funcionalidade discursiva" dos gêneros.

Em vista desses principais conceitos e definições, ressaltaremos, na subseção a seguir, os pressupostos que embasaram nossa metodologia de trabalho.

\section{A Leitura na Escola}

Mais do que decodificação de símbolos socialmente compartilhados, a leitura pressupõe atribuição de significados ao que se lê - o que comporá, de fato, a habilidade leitora. Contudo, nem sempre foi assim. Ao longo da história, a leitura como propiciação do saber e da compreensão ficava a cargo apenas de alguns literatos, intelectuais e elites. Para a maioria da população, principalmente no contexto ocidental dos séculos XVI e XVII, a leitura estava vinculada à religião. Portanto, era aprendida mecanicamente, de forma apenas a reproduzir os textos litúrgicos - que estavam em latim.

De modo geral, o processamento da leitura transpôs-se da necessidade do contato com o sagrado para uma necessidade pragmática - conhecer pontos de vista e culturas diferentes, aprender a manusear equipamentos e ferramentas, entrar em contato com o eu e com a ficção, etc. Nessa perspectiva, a linguística textual contribuiu bastante para o desenvolvimento das pesquisas sobre leitura, nessa mudança histórica. Primeiro, porque forneceu mecanismos para a acepção de texto: o texto, que antes recebia tratamento científico em nível de frase, passa a ser visitado como uma unidade global.

Outra grande contribuição da linguística textual concerne ao foco da leitura: aquelas que concentram o sentido no autor (língua como representação de pensamento); as que concentram o sentido no produto, no texto (língua como estrutura); e as leituras que focalizam o sentido na interação autor, texto e leitor (concepção dialógica da língua). Essa última é a acepção 
atualmente assumida pela Linguística Textual, possibilitando um salto qualitativo na forma de entender o texto (KOCH; ELIAS, 2012).

Esse breve apontamento histórico contribui para algumas reflexões aqui levantadas. Se a escola é um lugar facilitador para o ensino da leitura eficiente e eficaz, se é um espaço formal para a construção de um cidadão no mundo - o mundo contemporâneo dialógico -, que oportunidades de contato com a leitura os professores têm dado aos alunos? Têm, de fato, propiciado a esses sujeitos os sentidos possíveis do texto, com interação, discussão, diálogo com eles, ou apenas reproduzido a metodologia limitadora e "memorial" da Idade Média?

Ao ter em vista as diversas teorias que contribuem para a aplicação de estratégias linguísticas como procedimento de leitura, apresentamos, nesta subseção, um breve apanhado que pode ajudar a coadunar os procedimentos teóricos dos atos de fala e as teorias voltadas ao ensino da leitura como ato escolar.

Em primeiro lugar, entendemos que, como saída para um ensino eficaz, a atuação do professor pode ocorrer pelo viés interacional, levando o aluno a entrar em contato (de fato) com a leitura - a leitura dialógica. Exemplo disso é Cademartori (2009), que defende que, quando os leitores que se sentem tocados pelas obras lidas, são levados a mudanças práticas ou, ao menos, à aplicação de suas práticas à leitura.

Além dessa possibilidade social, a leitura de outros mundos, de outros modelos, de outras vozes, pode possibilitar a descoberta da própria voz do sujeito, outorgando-lhe uma autonomia possível. Portanto, o leitor de livros aprende a ser leitor do Outro - desenvolve a imagem do outro nele mesmo, o que contribui para a sua própria identificação. Tal imagem, apesar de cindida pela sociedade atual, não poderia estar assujeitada, mas liberada do Outro Opressor, pelo viés, por exemplo, da literatura (PARINI, 2007; CADEMARTORI, 2009).

Atualmente, não são apenas os textos literários que compõem as atividades educacionais de nossos alunos nas atividades com leitura. Textos cotidianos, em gêneros variados, de acordo com seus propósitos comunicativos, também, inserem-se nessa dinâmica. Temos uma gama de textos, em uma literatura multifacetada, multitextualizada e multimodalizada, representando aquilo em que o mundo atual se tornou: híbrido. Porém essas 
mudanças propiciam que o leitor vá além de suas próprias fronteiras, com textos que acompanham e são acompanhados de ritmos verbais, visuais e de entrosamento entre gêneros distintos.

Com todas essas possibilidades e demandas, a forma de ensinar a leitura sinaliza muito mais do que métodos, mas modelos constituintes, como marcos teóricos, percepção do psiquismo humano - como aprende, como funciona intelectualmente, como podemos, portanto, instrumentalizá-lo. Assim, ler não é apenas reconhecer e valorizar os saberes que se traz consigo, mas possibilitar o desenvolvimento de habilidades que não se tem, ou seja, a leitura crítica. Isso demanda um saber teórico por parte dos professores.

Entendemos que bons professores são aqueles que conduzem seu trabalho de forma a contribuir para o desenvolvimento crítico do aluno, pois não entendem a educação pelo viés do desempenho, mas como oportunidade de potencializar linguisticamente os alunos para o seu desenvolvimento leitor.

Uma atividade com tal perfil não se limita a discutir a importância da leitura ou a ensinar técnicas de leitura, mas leva o leitor a envolver-se com a leitura. Nesse caso, a materialidade linguística do texto é assumida como ferramenta para desconstruí-lo e para reconstruí-lo como um perito. Portanto, esse processo pode ser potencializado se o próprio professor tiver conhecimento dos fatos linguísticos realizados no texto.

Para esse fim, Abarca e Rico (2003) sugerem que, no desenvolvimento do trabalho com leitura, sejam feitas perguntas específicas, mediadoras, que levem o aluno, ainda em desenvolvimento da identidade leitora a pensar sistematicamente no "texto" e a ser direcionado à reflexão. Assim, perguntas gerais com possibilidade de respostas genéricas e abrangentes não parecem eficientes para os propósitos da autonomia.

Defendemos, ainda, que não apenas o processamento cognitivo interfere na formação do leitor, mas, também, o contexto em que se insere o aluno. Segundo Ferraz (2007, p 18), “o lugar onde se nasce, os meios social e cultural, associados eventualmente a fatores econômicos, marcam a diferença do capital lingüístico armazenado", fator que pode influenciar na habilidade de abstração de um determinado conteúdo textual.

Finalmente, acreditamos que o aluno precisa saber para que está lendo: para cumprir uma atividade burocrática? Para responder a uma questão da 
prova? Para passar o tempo de aula? E a função essencial do professor, nesse sentido, será a de mostrar ao aluno as tantas possibilidades de uma leitura, principalmente, a de se revelar como apontamento para o mundo real.

\section{Pressupostos Metodológicos}

Para compor os corpora da pesquisa foram usados quatro textos de caráter instrucional. Eles foram selecionados para análise das frases e enunciados realizadores de ações que se prestam aos objetivos dos quatro gêneros. As tarefas abarcadas por esses textos correspondem às etapas de execução, exigidas para atingir as finalidades desses enunciados e que objetivam instruir tarefas cotidianas comuns para solucionar problemas habituais dos indivíduos.

Por ser um trabalho de cunho interpretativo (ALVEZ-MAZZOTTI, 1999), não nos concentramos em quantificar os achados, mas em tentar detalhar as especificidades dos textos. Para isso, foram escolhidos exemplares acessíveis, que podem ser encontrados facilmente em lojas e departamentos comerciais. A seleção foi realizada entre os anos de 2009 e 2012, por meio da compra de produtos aos quais eles se propõem a instruir, todos adquiridos na cidade do Rio de Janeiro.

A fim de demonstrar as análises e discutir os resultados, escolhemos aleatoriamente um texto exemplar de cada gênero, os quais foram usados para explicitar alguns aspectos advindos da leitura, a partir dos textos instrucionais.

Os exemplos retirados dos corpora foram vistos de forma a verificar, primordialmente, o motivo das possíveis diferenças na interpretação de sentidos a partir das instruções, feitas por meio de frases imperativas e declarativas, prioritariamente. Essas frases, embora apresentem as mesmas finalidades de interpretação - que é a estipulação de etapas de procedimentos -, acarretam modos de instruir diferenciados.

A teoria dos Atos de Fala pode oferecer pistas para a leitura dos textos a partir das frases indicativas de procedimentos, subjacentes à configuração textual de uma receita, por exemplo. Sobre as formas de análise da linguagem, levantamos, nesta pesquisa, aspectos referentes à natureza 
enunciativa dos gêneros escolhidos que pudessem vislumbrar a elucidação de elementos comunicativos, focalizando a ação de instruir e priorizando a forma como os sentidos são assumidos, pelos interlocutores. Em seguida, debatemos esses achados linguísticos e os procedimentos de leitura possíveis no âmbito escolar.

\section{Análise e Discussão dos Dados}

Na presente seção, pretendemos ressaltar a ação pela linguagem, tendo como corpora textos instrucionais retirados de livros de receitas, manuais técnicos, bulas de medicamentos e contratos jurídicos. Os exemplares foram escolhidos por mediarem as situações enunciativas contextuais pressupostas pelo tipo injuntivo, cujas análises vislumbram contribuições com seu estudo.

\section{Da Receita}

Nesta subseção, iniciaremos a análise e as interpretações possíveis para os dados linguísticos, iniciando pelo exemplo 1, a seguir:

Exemplo 1: Receita

Frango com quiabo

INGREDIENTES

1 colher (sopa) de óleo

\section{1 frango inteiro cortado nas juntas $(1,5 \mathrm{~kg})$}

1 cebola grande picada

2 dentes de alho picados

1 colher (chá) de colorau

2 cubos do caldo de galinha

2 xícaras (chá) de água

Sal e molho de pimenta vermelha a gosto

3 xícaras (chá) de quiabo fatiado

Suco de 1 limão

Aqueça uma panela em fogo médio com o óleo e doure os pedaços de frango. Adicione a cebola, o alho, o colorau e refogue por 5 minutos. 
Despeje o caldo de galinha dissolvido na água, sal, molho de pimenta e cozinhe com a panela tampada por 35 minutos. Se necessário, adicione mais água. Adicione o quiabo e regue com o suco de limão. Refogue por 15 minutos, mexendo, ou até o quiabo amaciar e a baba sair. Transfira para uma travessa e sirva decorado a gosto.

Dica: se desejar, substitua o molho de pimenta por pimenta dedo-de-moga sem sementes, fatiada.

O Exemplo 1 refere-se a uma receita regional, explicando o modo de preparação do frango com quiabo. Nesse caso, o que pretendemos ressaltar é que a força ilocutória de sugestão pode ser configurada, também, a partir da escolha dos indivíduos, sendo ela reconhecida pelo locutor do texto.

O uso da expressão "a gosto" para demonstrar as quantidades de alguns elementos, como o "sal", o "açúcar" e a "pimenta", é comum na escrita desses textos. Isso ocorre, por exemplo, no fragmento "Sal e molho de pimenta vermelha a gosto". O mesmo ocorre com o uso da expressão "se desejar". Nesses casos, a instrução indica, no perlocucionário, a permissividade da influência do gosto dos indivíduos, de modo a evidenciar a aceitação dos procedimentos, de acordo com a preferência do interlocutor.

Reiteramos que um macroato ${ }^{1}$ de sugestão também fica latente quanto ao reconhecimento do acatamento ou não do que é sugerido, mostrando esse reconhecimento do locutor, por exemplo, pelo uso da imperativa "se desejar, substitua o molho de pimenta porpimenta dedo-de-moça sem sementes, fatiada", procedimento que vem a evidenciar esse caráter permissivo do gênero. Por fim, entendemos ser importante ressaltar que o caráter sugestivo das instruções parece estar na simplicidade com que os procedimentos são transmitidos.

Antecipamos, aqui, que nas receitas e nos contratos, o locucionário, com a exposição de frases declarativas, muitas vezes, presta-se a estipular procedimentos acolhidos no ilocucionário como diretivos. Já nos manuais, as descrições dos produtos, expostas por meio de atos assertivos, também podem reforçar o emprego dos diretivos.

${ }^{1}$ O termo "macroato" se refere à abordagem interacionista de Van Dijk (1977) e refere-se à totalidade intencional de determinado texto, deixando de se limitar à esfera frasal. 


\section{Do Manual}

Com o objetivo de mostrar outras formas de construção do texto instrucional, visto segundo os seus atos de fala, analisaremos um exemplar do gênero manual, conforme Exemplo 2, na sequência.

\section{Exemplo 2: Manual}

Uma mensagem multimídia pode conter texto, fotos, clipes de som e videoclipes. Somente dispositivos que possuam funções compatíveis poderão receber e exibir mensagens multimídia. A aparência de uma mensagem pode variar, dependendo do dispositivo receptor.

O Exemplo 2 foi retirado do manual de instruções do celular "Nokia". Nesse excerto, podemos perceber o emprego de frases que são usadas para descrever características do artefato, um aparelho de telefonia celular que pode ser usado para escrever mensagens.

A característica básica das ações comportadas pela categoria assertiva é informar uma propriedade que pode ser avaliada, de acordo com o critério de "verificabilidade", tal como evidenciado por Searle (2002), como possuidora de atributos como plausíveis de serem aceitos como "verdadeiros" ou "falsos". Nesse caso, o emprego das declarativas munidas dessa propriedade linguística pode prestar-se à finalidade de dar credibilidade ao produto adquirido, refletindo um ato de fala indireto, tal qual "você poderá enviar mensagens contendo textos, fotos, etc.", conferindo ao produto maior aceitação.

Com o objetivo de dar tal credibilidade ao que foi adquirido, o recurso linguístico utilizado é, portanto, o emprego de declarativas, como nas sequências "Uma mensagem multimidia pode conter texto, fotos, clipes de som e videoclipes" e "A aparência de uma mensagem pode variar, dependendo do dispositivo receptor". Desse modo, o que se pode apreender a partir da leitura dessas frases é que elas podem destacar, no ilocucionário, a preocupação com a valorização do produto adquirido. Esse traço interlocutivo pode refletir o desejo do locutor do texto, podendo ser interpretado como realizando o diretivo 
indireto "o produto adquirido é bom, pois pode ser usado para escrever mensagem" ou o assertivo "as mensagens ainda podem conter clipes, som, imagens, etc.".

As consequências para a leitura dos procedimentos podem acarretar, no perlocucionário, a aceitação ou a valorização das propriedades do artefato que serão, portanto, ideais para as suas finalidades de uso. Assim, as declarativas nos textos de manuais, também, podem denotar a tendência por promover, no ilocucionário, a evidenciação dos benefícios dos produtos adquiridos, por meio de atos de fala indiretos.

Porém, chamar a atenção dos indivíduos quanto aos riscos envolvidos no manuseio dos artefatos, igualmente, é uma tendência observada no gênero manual. Desse modo, muitas vezes, o emprego de palavras ou sentenças que se prestam a promover o acatamento imediato de comandos tidos por válidos, no perlocucionário, é outro aspecto relevante para a percepção dos sentidos.

Da Bula

Nesta subseção, analisaremos um exemplar do gênero bula. O exemplo, retirado da bula do suplemento vitamínico Kalyamon Kids, expõe sobre os benefícios do uso do medicamento no organismo, conforme Exemplo 3:

Exemplo 3: Bula

\section{INFORMAÇÕES AO PACIENTE COMO ESTE MEDICAMENTO FUNCIONA?}

Kalyamon ${ }^{\circledR}$ Kids é um suplemento vitaminico-mineral que possui uma combinação racional de todos os elementos essenciais à prevenção e combate dos estados de deficiência de cálcio. [...]

\section{QUANDO NÃO DEVO USAR ESTE MEDICAMENTO? Contra-indicações}

Não tome Kalyamon ${ }^{\circledR}$ Kids se você tiver hipersensibilidade (alergia) a qualquer um dos componentes do medicamento.

Kalyamon ${ }^{\circledR}$ Kids não deve ser utilizado nos seguintes casos:

Hipercalcemia (excesso de cálcio no sangue); Hipercalciuria (excesso de cálcio na urina); 
O Exemplo 3 constitui as partes que explicam sobre o funcionamento e as precauções para a ingestão do "Kalyamon Kids", um suplemento de cálcio bastante comum, usado pelas crianças na fase de dentição. Revela-se que o emprego de frases declarativas e imperativas procura assegurar a aplicação do produto e mostrar os riscos de seu uso, o que insere os atos de fala decorrentes do emprego dessas frases nas categorias diretiva ou assertiva.

A declaração feita pela frase: "Kalyamon ${ }^{\circledR}$ Kids é um suplemento vitaminicomineral que possui uma combinação racional de todos os elementos essenciais à prevenção e combate dos estados de deficiência de cálcio", pode conferir ao produto o indicativo de que ele serve para sua finalidade de uso, no caso, o combate à falta de cálcio no organismo.

A frase em destaque, embora declarativa, também, pode indicar, no perlocucionário, o mesmo objetivo de uso das imperativas. Nesse caso, ela se presta a instruir o interlocutor do uso da droga, objetivo que pode ser entendido se a considerarmos como desencadeadora do ato diretivo indireto "use esse medicamento para combater as carências de cálcio", por exemplo.

Já com respeito às sequências imperativas, que tradicionalmente se prestam a instruir os indivíduos, nas bulas, seu emprego reflete a presença de outro interlocutor que não é o paciente, visto que as instruções são passadas para o médico, e não para o paciente em si. Isso pode ser visto ao analisarmos o emprego da imperativa "Kalyamon ${ }^{\circledR}$ Kids não deve ser utilizado nos seguintes casos: Hipercalcemia (excesso de cálcio no sangue); Hipercalciúria (excesso de cálcio na urina)". Esse período, embora esteja sendo direcionado ao profissional de saúde, pode acarretar, no ilocucionário, o aviso quanto à não utilização do medicamento por alguns indivíduos. Quando isso ocorre, demanda-se um ato de fala que se presta a provocar o devido acatamento, no perlocucionário, do procedimento expresso por essa frase, com força ilocutória de imposição. Por conta das diferenças de emprego frasal, as formas de acatamento, à luz dos efeitos ilocutórios das declarativas e imperativas, são diferenciadas no gênero, sempre dependendo dos riscos envolvidos.

Dirigir-se ao profissional de saúde e não à pessoa que irá manusear o medicamento pode, por fim, provocar uma leitura dos procedimentos, assim, acarretando outras formas de acatamento dessas instruções, de acordo com as temeridades envolvidas. Isso pode evidenciar outros posicionamentos do indivíduo que ingerirá a droga, havendo repercussões na percepção dos 
sentidos a partir dessas ações e seus desdobramentos para o entendimento do interlocutor.

Do Contrato de Adesão

Nesta subseção, analisaremos o último exemplar pertencente ao gênero contrato. Vejamos o Exemplo 4, que segue.

\section{Exemplo 4: Contrato}

3.2 O Assinante reconhece que os serviços poderão eventualmente ser afetados ou interrompidos, não sendo a Claro responsável por eventuais falbas, atrasos ou interrup̧̧ões destes, inclusive por caso fortuito ou força maior, e pela atuação de outras prestadoras de serviços de telecomunicações interconectadas à rede da Claro, por imposições governamentais, por má utilização do serviço ou da EM pelo Assinante ou por qualquer outro fato ou ato alheio à sua vontade ou fora de seu controle.

3.3 A Claro obriga-se a prestar o SMP segundo os padrões de qualidade exigidos pela Anatel.

3.4 O Assinante declara ter ciência das localidades cobertas pelo SMP, das limitações decorrentes de eventuais áreas com limitação de sinal e da disponibilidade de rede e, em hipótese alguma, o Assinante se desobrigará do pagamento do serviço sob alegação de não abrangência do SMP em certa área.

No Exemplo 4, mostram-se algumas cláusulas do contrato da empresa Claro. Nele, as instruções, muitas vezes, são feitas de modo a eximir os contratados, que são as empresas responsáveis pelo serviço, e as declarativas se prestam a expressar regras que precisam ser interpretadas de modo a não oferecer riscos jurídicos às empresas. Essa atribuição interlocutiva pode ser vista na declarativa " $O$ Assinante reconhece que os serviços poderão eventualmente ser afetados ou interrompidos, não sendo a Claro responsável por eventuais falbas, atrasos ou interrupções destes". Essa frase realiza, indiretamente, a instrução "reconheça que a Claro não será responsável se houver falhas, atrasos ou interrupções na prestação de serviços", que é um ato de fala indireto de natureza diretiva. 
A predisposição de procedimentos por meio de Atos de Fala indiretos, representados por declarativas é, portanto, uma marca interlocutiva importante desses textos. Todavia, o oferecimento de benefícios também é indicado como decorrente do emprego desse tipo frasal. Esse emprego pode ser visto por meio da declarativa "A Claro obriga-se a prestar o SMP segundo os padrões de qualidade exigidos pela Anatel', que pode servir para atenuar a imposição feita anteriormente, podendo desempenhar papel semântico de diminuir o aspecto negativo do serviço oferecido decorrente da aquisição do celular pelo cliente.

$\mathrm{Na}$ continuação da cláusula, a declarativa "O Assinante declara ter ciência das localidades cobertas pelo SMP, das limitacōoes decorrentes de eventuais áreas com limitação de sinal e da disponibilidade de rede e, em hipótese alguma o Assinante se desobrigará do pagamento do serviço sob alegação de não abrangência do SMP em certa área" volta a impor uma condição ao que foi oferecido anteriormente. Nesse caso, a declarativa citada realiza a instrução "declaro saber quais localidades são cobertas pela operadora e não deixarei de fazer os pagamentos, ainda que o serviço não esteja sendo prestado pela Claro", ato diretivo indireto.

Sobre essa ocorrência, o que se pretende ressaltar na análise das esferas interlocutivas definidas pelas instruções é que, tanto na verificação das frases com natureza declarativa que preconizam procedimentos quanto no entendimento das informações com vistas a impor as regras contratuais, no perlocucionário, o acatamento dos comandos é incondicional. Essa força ilocutória impositiva indica que o não acatamento do que é instruído poderá refletir em penalidades jurídicas para as partes envolvidas na contratação.

Assim, ressalta-se que, embora não possuindo superficialmente instruções feitas por meio de imperativas, o gênero contém instruções cujo impacto, no perlocucionário, pretende ser de maior poder impositivo do que nos demais gêneros.

\section{Gêneros Instrucionais e Leitura na Escola: uma intercessão possivel}

Defendemos aqui que a teoria dos Atos de Fala pode acrescentar perspectivas diferenciadas quanto à leitura dos diferentes textos porque os níveis ilocutórios dos Atos de Fala apontam três patamares de observação da linguagem. Para além dessas esferas de observação das informações, 
advindas dos textos, a contribuição dessa vertente teórica privilegia os interagentes, que são os elementos centrais na troca interlocutiva. Por isso, o estudo dos diferentes tipos e gêneros à luz das ações demandadas pelos interlocutores torna-se importante, pois a linguagem passa a demonstrar não apenas os "sentidos" por ela demandados, mas a intencionalidade dos indivíduos.

Pelo teor instrucional dos gêneros aqui estudados - a receita, o manual, a bula e o contrato -, selecionamos para esta análise um exemplar de cada gênero. Além disso, objetivamos analisar a correlação entre essa análise e a combinação texto-aluno-professor, visto entendermos que essa interação pode possibilitar que o processamento da leitura seja efetivo, contextualizado e que, principalmente, parta de um viés linguístico.

A primeira contextualização a ser feita é que 1) se o professor não tiver acesso a informações teóricas, como as resumidas neste trabalho; ou 2) se ele não for confrontado com os variados usos linguísticos possíveis nos gêneros instrucionais (como no caso das análises linguísticas demonstradas neste trabalho, que mostram que a injunção, nestes gêneros, não está marcada apenas pelo imperativo), os alunos tenderão a reproduzir a ideia de que devem se concentrar nos verbos categorizados como imperativos.

Nesse sentido, entendemos alguns aspectos como essenciais: a) o ensino da gramática - modos verbais, pontuação, etc. - não deveria estar estanque do texto, nem de suas funções expressivas; b) os estudos teóricos sobre os gêneros pertencentes ao tipo injuntivo deveriam receber mais atenção nos estudos da linguagem, visto que há um nicho considerável a ser preenchido nesse sentido.

Entendemos ainda que, se os estudos dos gêneros aqui citados continuarem na atual perspectiva da caracterização linguística, haverá uma reprodução desses gêneros em nível metalinguístico, cuja análise se distanciará do projeto de dizer dos gêneros em questão, afastando-os de suas possibilidades de interação real - e de ação.

Defendemos também que, ao deparar-se com atividades com esses gêneros, se o aluno tiver um prévio conhecimento conceitual, mas também prático - das possibilidades de a língua servir às especificidades e aos propósitos comunicativos do texto/gênero -, ele poderá de fato realizar leituras autônomas. 
Duas considerações podem ser feitas, portanto, a partir dos resultados das análises linguísticas expostas nas subseções anteriores. A primeira referese ao conhecimento de mundo dos alunos. Expô-los a gêneros textuais do cotidiano dos cidadãos, mas pouco utilizados por eles como adolescentes como contratos e instruções, voltados para suas realidades -, pode ajudá-los a construir sentidos possíveis para o entendimento dos textos. Além disso, pode aumentar-lhes a instrumentalidade linguística, pois sairão de textos padronizados repetidos em sala de aula.

A segunda consideração refere-se à prática do pensamento crítico. Tomemos o Exemplo 4 da subseção anterior. Nele, as escolhas lexicogramaticais podem sugestionar um leitor sem que ele perceba, negligenciando-lhe a possibilidade da busca por seus direitos. Na construção linguístico-discursiva do exemplo em questão, os sentidos se constroem discursivamente, de forma a proteger "apenas" a empresa. Assim, o item 3.4, linguisticamente, "anula" o 3.3.

\subsection{A Claro obriga-se a prestar o SMP segundo os padrões de qualidade exigidos} pela Anatel.

3.4 O Assinante declara ter ciência das localidades cobertas pelo SMP, das limitaçôes decorrentes de eventuais áreas com limitação de sinal e da disponibilidade de rede e, em hipótese alguma, o Assinante se desobrigará do pagamento do serviço sob alegação de não abrangência do SMP em certa área.

Sabemos que pensar é uma construção e que leitura é pensamento; portanto, a percepção dos sentidos, a partir desse fragmento, subentende que a habilidade ledora também se dá em um processo. Contudo, com tantas leituras rápidas, com instruções “dadas” em nosso cotidiano, tanto escolar quanto social, interpretamos que mostrar ao nosso aluno-leitor que ele pode ser influenciado por meio das várias estratégias linguísticas nos textos injuntivos, e não apenas a partir dos comandos, pode contribuir para sua autonomia e inserção crítica no mundo.

Esse trabalho em sala de aula pode ser feito de forma estratégica. Retomando Abarca e Rico (2003), a necessária pergunta específica pelo viés dos dados encontrados nos gêneros aqui estudados pode mediar o processo de leitura e levar o aluno, ainda em desenvolvimento de processamento de 
leitura autônoma, a pensar no texto de forma sistemática, utilizando-se das ferramentas linguísticas nele disponíveis, sendo, portanto, direcionado à reflexão. Desse modo, as perguntas generalizadoras, com possibilidades de respostas amplas, não ajudariam nesse processo.

Além disso, se o professor reconhecer que o contexto sociocultural desse aluno contribui para o seu fazer leitor, ele pode selecionar textos pertencentes a outros gêneros que abordem o mesmo tema, com vistas a ampliar a discussão do assunto contido no gênero instrucional e, por conseguinte, fornecendo-lhe dados do mundo e leituras possíveis. Dessa forma, pensamos que a linguagem será ato não apenas no "processamento linguístico do gênero", mas, também, na "construção do sujeito autônomo" para produzir, e não apenas reproduzir.

\section{Considerações Finais}

Neste artigo, propusemos a análise de quatro textos instrucionais, tendo como base as frases usadas para indicar procedimentos. Cada um dos textos é possuidor de atributos discursivos diferenciados, ao considerarmos os atos de fala inerentes às frases. A receita tem como característica discursiva principal a flexibilidade quanto ao acatamento das instruções, acolhendo um macroato de fala compatível com a ação de "sugestão"; já o manual, por instruir por meio de procedimentos que se prestam a mostrar a periculosidade envolvida no manuseio dos produtos, preconiza o macroato de "advertência"; a bula de medicamentos prioriza a instrução dos indivíduos que irão ingerir o remédio, idealizando o macroato de "prescrição"; o contrato, por sinalizar as atitudes que os contratantes terão de efetuar juridicamente na manutenção dos direitos de uso, acolhe o macroato de "imposição", tendo como efeito procedimentos obrigatórios.

Todos esses macroatos podem ser analisados, também, no cotejo da perspectiva do produtor dos enunciados com a do leitor. Essa relação pode ser observada ao examinarmos os níveis de Atos de Fala. O ilocucionário está coadunado à intencionalidade dos falantes ao proferirem as instruções, sendo ele importante se ainda mencionarmos a percepção das forças ilocutórias inerentes a essas ações. Em contrapartida, o perlocucionário mensura o modo como as instruções são efetuadas pelos interlocutores, 
também de acordo com o tipo de força ilocutória que baliza a natureza dos procedimentos e instruções. Dessa forma, todos os atributos relacionados ao efetivo cumprimento dos procedimentos são efetuados no perlocucionário e, por conseguinte, tais efeitos interlocutivos estão subjacentes à leitura e assimilação dos sentidos dos textos de natureza instrucional.

Reconhecemos que um dos aspectos limitadores desse trabalho reside na seleção de quatro gêneros, quando muitos outros são também de base instrucional, como a prova, orientações acadêmicas, regras de jogos, entre outros. Contudo, entendemos que a leitura dos enunciados ora selecionados pode dimensionar uma abordagem importante quanto ao tipo injuntivo, pois essa tipologia, tradicionalmente vista para a elaboração de atitudes de ordem ou comando, pode ser analisada a partir da gradação impositiva dos atos diretivos. A tipologia injuntiva acarreta, portanto, níveis das instruções que vão desde a sugestão à imposição, sempre equiparando essas formas enunciativas ao gênero em que ela se veicula. Entendemos, também, que o tipo textual em tela precisa ser mais pesquisado, no contexto dos estudos linguísticos, visto que não existe uma tradição em sua análise. Essa necessidade decorre das finalidades de aplicação dessa tipologia que, embora seja imprescindível na configuração de textos que se prestam à realização de tarefas do cotidiano discursivo dos indivíduos de todas as esferas sociais, não constitui uma temática ordinária, no seio dos estudos acadêmicos. Entendemos, por fim, que esse avanço promove inclusive avanços nas atividades com leitura funcional e autônoma no desenvolvimento do sujeito leitor nas escolas.

\section{Referências}

ABARCA, E. V.; RICO, G. M. Por que os textos são tão difíceis de compreender? As inferências são a resposta. In: TEBEROSKY, A. et al. Compreensão de leitura - a língua como procedimento. Porto Alegre: Artmed, 2003. p. 139-153.

ALVEZ-MAZZOTI, A. J.; GEWANDSZNAJDER, F. O método nas ciências naturais e sociais: pesquisa quantitativa e qualitativa. 2. ed. São Paulo: Pioneira, 1999. 
AUSTIN, J. L. How to do things with words. Cambridge, Massachusetts: Harvard University Press, 1962.

AUSTIN, J. L. Quando dizer é faz̧er: palavras e ação. Tradução Danilo Marcondes de Souza Filho. Porto Alegre: Artes Médicas, 1990.

BAKHTIN, M. Estética da criação verbal. 2. ed. São Paulo: Martins Fontes, 1997 [1959].

CADEMARTORI, L. O Professor e Literatura - para pequenos, médios e grandes. Belo Horizonte: Autêntica, 2009.

CHARAUDEU A. P.; MAINGUENEAU, D. Dicionário de análise do discurso. 2. ed. São Paulo: Contexto, 2002.

DIJK, T. A. van. Text and context. London; New York: Longman, 1977.

FERRAZ, M. J. A língua materna ensina-se? In: FERRAZ, M. J. Ensino da lingua materna. Lisboa: Caminho, 2007. p. 17-25.

KOCH, I. V.; ELIAS, V. M. Ler e escrever - estratégias de produção textual. 2. ed. São Paulo: Contexto, 2012.

PARINI, J. A arte de ensinar. Rio de Janeiro: Civilização Brasileira, 2007.

RAJAGOPALAN, K. Atos ilocucionários como jogos de linguagem. Estudos Lingüísticos, Campinas, n. 18, p. 523-529, 1989.

SEARLE, J. Speech acts: an essay in the Philosophy of Language. New York: Cambridge University Press, 1969.

SEARLE, J. Os actos de fala: um ensaio de filosofia da linguagem. Coimbra: Livraria Almedina, 1981.

SEARLE, J. Expressão e significado: estudo da teoria dos atos de fala. 2. ed. São Paulo: Martins Fontes, 2002.

Recebido em: 04/09/2015

Aceito: 11/04/2016 